\title{
Visceral composition, carcass yield and meat quality parameters of free-range broilers with diets containing different levels of crushed sugarcane
}

Composição visceral, rendimento de carcaça e parâmetros de qualidade da carne de frangos caipira com dietas contendo diferentes níveis de cana-de-açúcar triturada

RESENDE, Viviane Assunção de ${ }^{1}$ https://orcid.org/0000-0001-5199-6408

TEIXEIRA, Alexandre de Oliveira ${ }^{2 *}$ https://orcid.org/0000-0001-8700-9611

MOREIRA, Leonardo Marmo ${ }^{2}$ https://orcid.org/0000-0002-1792-1741

CORASSA, Anderson ${ }^{3}$ https://orcid.org/0000-0002-3969-3065

PIRES, Christiano Vieira ${ }^{2}$ https://orcid.org/0000-0002-4182-0772

\author{
VALENTE JÚNIOR, Dante Teixeira ${ }^{4}$ \\ https://orcid.org/0000-0001-9344-2016 \\ VIDIGAL, Márcia Cristina Teixeira \\ Ribeiro $^{5}$ \\ https://orcid.org/0000-0002-8065-0753 \\ GAYA, Leila de Genova ${ }^{2}$ \\ https://orcid.org/0000-0001-5004-1394
}

BRIGHENTI, Carla Regina Guimarães ${ }^{2}$ https://orcid.org/0000-0002-7822-3744

${ }^{1}$ Zootecnista, Universidade Federal de Lavras, MG, Brasil.

${ }^{2}$ Professores do Departamento de Zootecnia/Universidade Federal de São João Del Rei (UFSJ), MG, Brasil.

${ }^{3}$ Professor do Departamento de Zootecnia/Universidade Federal do Mato Grosso, Sinop Campus, MT, Brasil.

${ }^{4}$ Doutorando em Zootecnia, Universidade Federal de Viçosa, Viçosa Campus, MG, Brasil.

${ }^{5}$ Professora do Departamento de Tecnologia de Alimentos/Universidade Federal de Viçosa, Viçosa Campus, MG, Brasil.

* Mailing address: alexandre_teixeira@ufsj.edu.br

\begin{abstract}
The aim of this study was to evaluate the visceral composition, cuts, and meat quality of two strains of free-range chickens fed diets containing crushed sugar cane. 448 chickens were distributed at 35 days of age, in two randomized blocks design, in $4 \times 2$ factorial, with four levels of replacement in the feed $(0 ; 15 ; 30$ and $45 \%)$ by sugarcane and two strains (Pesadão and Label Rouge), in two repetitions per block of fourteen birds per experimental unit. In 30 minutes after slaughter, the parameter a* was higher for animals of the Pesadão strain relation to the Label Rouge lineage. A quadratic effect was observed with increasing levels of sugarcane on the $\mathrm{L}^{*}$ parameter of breast meat; and linear effect on parameter $b^{*}$ of the breast skin. Within 24 hours after slaughter, a quadratic effect of sugarcane levels was observed on the $b^{*}$ parameter of the breast meat. The increase in sugarcane levels linearly reduced the weight of heart, liver, chest, thigh plus drumstick, wing, carcass yield and relative heart weight of the animals. A quadratic effect was
\end{abstract}


observed with increase in sugarcane levels over the relative weight of abdominal fat, the lowest fat content was observed in animals that consumed up to $30 \%$ of sugarcane in the feed. The use of sugarcane as an alternative feedstuff in up to $45 \%$ in the diet maintains the quality of meat and reduces the abdominal fat content, however, decreases the carcass yield.

Keywords: alternative feeds, body composition, fiber, organic production, poultry

\section{RESUMO}

Objetivou-se com este trabalho avaliar a composição visceral, o rendimento de cortes e a qualidade de carne de duas linhagens de frangos tipo caipira alimentados com dietas contendo cana-de-açúcar triturada. Foram utilizados 448 frangos distribuídos, aos 35 dias de idade, em dois blocos casualizados, em esquema fatorial $4 \times 2$, sendo quatro níveis de substituição da ração $(0 ; 15 ; 30$ e $45 \%)$ por de cana-de-açúcar e duas linhagens (Pesadão e Label Rouge), em duas repetições por bloco de quatorze aves unidade experimental. Em 30 minutos após o abate, o parâmetro a* foi maior para os animais da linhagem Pesadão em relação à linhagem Label Rouge. Observou-se efeito quadrático com o aumento dos níveis cana-de-açúcar sobre o parâmetro $L^{*}$ da carne do peito; e efeito linear sobre o parâmetro $b^{*}$ da pele do peito. Em 24 horas após o abate, observou-se efeito quadrático dos níveis de cana-de-açúcar sobre o parâmetro $b^{*}$ da carne do peito. $\mathrm{O}$ aumento dos níveis de cana-de-açúcar reduziu linearmente o peso do coração, fígado, peito, coxa mais sobrecoxa, asa, rendimento de carcaça e peso relativo do coração dos animais. Observou-se efeito quadrático com o aumento dos níveis de cana-de-açúcar sobre o peso relativo da gordura abdominal, sendo que o menor teor de gordura foi observado nos animais que consumiram até $30 \%$ de cana-de-açúcar. O uso da cana-deaçúcar como alimento alternativo em até $45 \%$ na dieta, possibilita manter a qualidade de carne e reduz o teor de gordura abdominal, porém, diminui o rendimento de carcaça.

Palavras-chave: alimentos alternativos, aves, composição corporal, fibra, produção orgânica

\section{INTRODUCTION}

Broiler and organic production systems were developed following a tendency of concerns focused on human health and nutrition (Stadig et al., 2016; Ipek \& Sozcu et al., 2017). Consumers attribute higher quality and safety to the meat obtained in these alternative systems This kind of breeding is also associate to excellent levels of animal welfare (Castromán et al., 2013). Thereby, the industry has demonstrated higher interest in improving the yield of carcass and noble parts due to the consumers demand for meat with good conformation and less quantity of lipids. In this way, alternative chicken production has showed sensorial alterations of the meat (Ponte et al., 2008b), lipid level variation (Funaro et al., 2014), and modification in the fatty acids pattern (Funaro et al., 2014) when compared with the conventional production.

The use of alternative feeds, such as whole cassava meal (Holanda et al., 2015), pigeon bean (Alencar et al., 2014), alfafa meal (Zheng et al., 2018), kernel maize silage (Ranjitkar et al., 2016), sugarcane bagasse (Kheravii et al., 2017), rice bran, and manioc leaves 
(Faria et al., 2011), have been demonstrated as interesting options in the broiler chicken production. Sugarcane is an energetic food that is rich in saccharose, with low levels of crude protein, high levels of fiber (Cruz et al., 2014), and great potential to be employed due to its availability (Leal et al., 2013).

Indeed, the great sugar cane production in Brazil as well as its low cost and availability should favor its employment in animal production (Leal et al., 2013). Sugar cane could be applied in drought periods. It could also be benefic in crowded and/or poorly managed paddocks, in which chicken are left without forage. In fact, the presence of forage is one of the characteristics of the free-range chicken production system (Faria et al., 2011). In addition, the inclusion of sugar cane in the feed can be used to control the deposition rate and the composition of the tissues in carcasses (Espósito et al., 2015). Consequently, such inclusion would improve the nutritional and organoleptic properties of the meat.

However, rough feed present high levels of fiber, which can decrease the use of nutrients by chicken with a subsequent reduction in the growth grade in the nutritional efficiency (Ponte et al., 2008a) and carcass composition (Faria et al., 2011). On the other hand, genetic groups of slow growth and environmental factors, such as alterations in feed composition could also change the expression of the genetic potential of the chicken regarding performance and growth properties (Souza et al., 2011).
The production of chicken through a more efficient alternative system in order to increase the number of alternative foods to the consumers still requires more efforts by researchers. In this way, the aim of present study was to evaluate the visceral composition, carcass yield and quality of broiler chicken meat originated of two strains fed with diets containing different levels of crushed sugarcane.

\section{MATERIAL AND METHODS}

All experimental protocols involving animals was approved by the Research Ethics Committee Involving Animals (CEPEA) at Federal University of São João Del Rei (UFSJ), São Jõao Del Rei, MG, Brazil (Protocol no. 10/2011).

The experiment was developed in the farm "Caipirão do Parque", in the city of Coronel Xavier Chaves, in the region Campos das Vertentes, Minas Gerais state, Brazil. The study involved 448 broiler chicken $(922 \pm 29 \mathrm{~g}$ with 35 days of age) organized in a factorial scheme $4 \times 2$, being four levels of substitution of the basic diet for sugar cane $(0,15,30$ and $45 \%$ ) and two commercial strains (Label Rouge and Pesadão), distributed in random blocks design, with four repetitions and 14 birds for experimental unit ( 7 males and 7 females).

The diets employed to the growth (between 35 and 60 days of age) and termination (between 61 and 85 days of age) phases contained, mainly, corn and soybean meal (Table 1) to achieve the broilers nutritional requirements of medium performance (Rostagno et al., 2005). 
Table 1. Calculated and percentual compositions of the basic diets to growth and termination phases

\begin{tabular}{|c|c|c|}
\hline Ingredients & $\begin{array}{l}\text { Growth } \\
\text { (35 to } 60 \text { days) }\end{array}$ & $\begin{array}{l}\text { Termination } \\
\text { (61 to } 85 \text { days) }\end{array}$ \\
\hline Corn & 64.61 & 73.51 \\
\hline Soybean meal $45 \%$ & 30.612 & 22.534 \\
\hline Soy oil & 1.440 & 1.321 \\
\hline Common salt & 0.330 & 0.255 \\
\hline Mineral supplement ${ }^{1}$ & 0.050 & 0.050 \\
\hline Vitaminic supplement $^{2}$ & 0.100 & 0.100 \\
\hline DL-methionine (99\%) & 0.168 & 0.108 \\
\hline L-lysine $\mathrm{HCl}(78 \%)$ & 0.117 & 0.041 \\
\hline Choline Chloride $70 \%$ & 0.050 & 0.050 \\
\hline Dicalcium phosphate & 1.322 & 1.222 \\
\hline Calcitic limestone & 1.209 & 0.809 \\
\hline Total & 100.000 & 100.000 \\
\hline \multicolumn{3}{|l|}{ Calculated composition } \\
\hline Crude protein $(\%)$ & 19.375 & 16.343 \\
\hline Metabolizable energy (kcal/kg) & 3,000 & 3,100 \\
\hline Calcium (\%) & 0.881 & 0.686 \\
\hline Available phosporum (\%) & 0.351 & 0.325 \\
\hline Sodium $(\%)$ & 0.15 & 0.12 \\
\hline Methionine + Digestible cystine $(\%)$ & 0.716 & 0.597 \\
\hline Digestible lysine (\%) & 1.006 & 0.760 \\
\hline Digestible threonine (\%) & 0.654 & 0.551 \\
\hline Digestible arginine (\%) & 1.212 & 0.984 \\
\hline Digestible tryptophan (\%) & 0.21 & 0.17 \\
\hline Digestible valine (\%) & 0.815 & 0.690 \\
\hline
\end{tabular}

${ }_{1}^{1}$ per kg of diet: Manganese, $75 \mathrm{mg}$; iron, $50 \mathrm{mg}$; zinc, $70 \mathrm{mg}$; copper, $8.50 \mathrm{mg}$; cobalt, $2 \mathrm{mg}$; iodine, $1.5 \mathrm{mg}$ and vehicle q.s.p. $1.000 \mathrm{~g}$.

${ }^{2}$ per kg of diet: Vit. A, 12.000 UI; vit. D3, 2.200 UI; vit. E, 30 UI; vit. B1, 2.2 mg; vit. B2, 6 mg; vit. B6, $3.3 \mathrm{mg}$; vit. B12, $16 \mathrm{mg}$; pantothenic acid, $13 \mathrm{mg}$; vit. $\mathrm{K} 3,2.5 \mathrm{mg}$; folic acid, $1 \mathrm{mg}$; selenium, $0.12 \mathrm{mg}$; antioxidant, $10 \mathrm{mg}$ and vehicle.

The chickens were disposed in 16 boxes $\left(2.5 \mathrm{~m}^{2}\right)$ localized in a shed with $3 \mathrm{~m}$ high. Each box was equipped with tubular feeder and pendular drinker. The 
animals had access to paddocks with 45 $\mathrm{m}^{2}$ each one, without forage.

The animals received experimental diets, which were elaborated based on isometric substitution of $0,15,30$ and $45 \%$ of basic diet (growth and termination) for crushed sugar cane (stem and leaves) in micer, in order to obtain an specific granulometry that propitiates a perfect mixture of ingredients. The sugar cane was crushed daily. During the experimental period, chickens received water ad libitum.

Crushed sugarcane samples were collected and sent to Animal Nutrition Laboratory of Animal Science Department at Federal University of Viçosa. and were analyzed following the methods described by Detmann et al. (2012). The sugarcane supplied to the birds had 29.79\% of Dry Matter (DM), which composition was as follows: Mineral Matter (3.5\%), Neutral Detergent Fiber (52.4\%), Ethereal Extract (1.74\%), Non-Fiber Carbohydrates (45.37\%), Crude Protein (3.01\%), Calcium (0.29\%) and Phosphorus $(0.06 \%)$.

The chickens were exposed to natural light, without any artificial light. The environmental temperature was obtained by thermometers of maximum and minimum temperature disposed in the room. The temperatures were registered twice a day ( $9 \mathrm{~h} 00$ and $17 \mathrm{~h} 00$ ), during the experimental period.

The animals were weighed at 85 days old. Subsequently, two animals (males) with weight near the average of the box were slaughtered per experimental unit, comprising 32 chickens. Animals were numb by cervical dislocation. Then, bleeding, scalding $\left(59^{\circ} \mathrm{C}\right.$ during $\left.120 \mathrm{~s}\right)$, plucking and evisceration were performed. The hot carcasses were weighed and their abdominal fat was removed.

Before cooling, breast meat of the chickens was evaluated regarding temperature, $\mathrm{pH}$ and color, at 30 minutes after slaughter and 24 hours after slaughter. For the evaluation of temperature, a digital bimetallic "skewer type" thermometer was employed. The $\mathrm{pH}$ determination of the meat was performed in the chest of chickens, by digital pHmeter (Jonhis, device IpHPJ). Subsequently, to determine the color of the breast meat (in the breast skin and thigh skin), we employed a colorimeter CR400 Konica Minolta, which considers the coordinate $\mathrm{L}^{*}$ (black/white) responsible for the luminosity, a* (green/red) for the intensity of red, and $b^{*}$ (blue/yellow) for the intensity of yellow, in agreement with CIELAB system, as described by Caldara et al. (2012).

The carcasses were submitted to the precooling processes (water in temperature around $20^{\circ} \mathrm{C}$ for 30 minutes) and cooling (water from 0 until $8^{\circ} \mathrm{C}$ for 15 minutes). After that, they were suspended for 5 minutes to elimination of the water excess. Subsequently, commercial cuts of breast, thigh, thigh plus thig were made, aiming to proceed the weighing and the calculus of the respective yields. The yield of carcasses (\%) was obtained through the relation between the cold carcass weight (without feet, head and neck) and the pre-slaughter live weight. The yields of breast, thigh plus thig and wing $(\%)$ were obtained through the relation between the weight of these parts and the weight of the cold carcass. The edible viscera liver, gizzard and heart also were weighed to absolute and proportional evaluation in the carcass. The proportions of liver, gizzard, and heart $(\%)$ were obtained through the ratio 
between the weight of these organs and the pos-slaughter weight.

The Student Newman Keuls test was used to compare the average of the parameters between the strains of chicken and the regression analysis was employed to evaluate the parameters as function of the levels of sugar cane inclusion. The level of significance used was $5 \%$, employing the functions linear and quadratic of the statistic software SAEG, version 4.0, licensed by the Federal University of Viçosa.

\section{RESULTS}

The minimum $\left(16.2 \pm 3.18^{\circ} \mathrm{C}\right)$ and maximum $\quad\left(25.12 \pm 4.65^{\circ} \mathrm{C}\right) \quad$ average environmental temperatures as well as the average relative humidity (76.46 \pm $13.88 \%$ ), during the experimental period were in the suitable limits to the chicken production.

There was no interaction between strains and treatments $(\mathrm{P} \geq 0.05))$ for the weight of the carcass in 30 minutes (Table 2) and in 24 hours after the slaughter (Table 3 ), as well as there was no effect of the substitution levels $(\mathrm{P} \geq 0.05)$ on the temperature and the $\mathrm{pH}$ of the carcass in 30 minutes (Table 2) and in 24 hours after the slaughter (Table 3 ).

In 30 minutes after the slaughter (Table 2 ), it was observed effect of strain $(\mathrm{P}<0.05)$ upon the intensity of red $\left(\mathrm{a}^{*}\right)$ to the color of the breast. This parameter was higher $(\mathrm{P}<0.05)$ for the animals of the strain "Pesadão" in relation to the strain Label Rouge (LR). It was observed a quadratic effect $(\mathrm{P}<0.05)(\mathrm{Y}=53.198$ $\left.-0.2088+0.0045 \mathrm{X}^{2}, \mathrm{R}^{2}=0.60\right)$ of the substitution levels of the diet for sugar cane upon the luminosity $\left(\mathrm{L}^{*}\right)$ of the breast meat; and linear effect $(\mathrm{P}<0.05)$ $\left(\mathrm{Y}=14.291+0.0679 \mathrm{X}, \mathrm{R}^{2}=0,61\right)$ upon the intensity of yellow $\left(b^{*}\right)$ of the breast skin. To the additional cuts, the color parameters were not influenced by the diet substitution for sugar cane or strain $(\mathrm{P}>0.05)$ in 30 minutes after slaughter.

Table 2. Effects of strain and substitution levels of the diet for sugarcane upon temperature, $\mathrm{pH}$ and the parameters of color, meat and breast skin, in 30 minutes after slaughter in the chickens

\begin{tabular}{|c|c|c|c|c|c|c|c|}
\hline \multirow{2}{*}{ Item } & \multirow{2}{*}{ Strain } & \multicolumn{5}{|c|}{ Diet substitution for sugarcane } & \multirow{2}{*}{$\begin{array}{l}\text { VC } \\
(\%)\end{array}$} \\
\hline & & $\mathbf{0 \%}$ & $15 \%$ & $30 \%$ & $45 \%$ & Average & \\
\hline \multirow{4}{*}{ Temperature } & Label Rouge & 30.56 & 29.06 & 26.49 & 28.68 & 28.70 & \\
\hline & Pesadão & 29.50 & 28.30 & 28.50 & 29.53 & 28.96 & \\
\hline & Average & 30.03 & 28.68 & 27.49 & 29.10 & 28.83 & 7.25 \\
\hline & Label Rouge & 5.66 & 5.84 & 5.68 & 5.62 & 5.70 & \\
\hline \multirow[t]{2}{*}{$\mathrm{pH}$} & Pesadão & 5.76 & 5.97 & 5.74 & 5.66 & 5.78 & \\
\hline & Average & 5.71 & 5.90 & 5.71 & 5.64 & 5.74 & 5.53 \\
\hline \multicolumn{8}{|l|}{ Breast meat } \\
\hline & Label Rouge & 52.74 & 52.99 & 49.44 & 55.24 & 52.60 & \\
\hline \multirow[t]{3}{*}{ Parameter L* } & Pesadão & 52.91 & 51.42 & 50.39 & 51.54 & 51.57 & \\
\hline & Average (Q) & 52.82 & 52.20 & 49.91 & 53.39 & 52.08 & 5.42 \\
\hline & Label Rouge & 1.03 & 0.57 & 1.49 & 0.57 & 0.92 & \\
\hline \multirow[t]{2}{*}{ Parameter $a^{*}$} & Pesadão & 0.89 & 1.19 & 0.94 & 1.12 & 1.04 & \\
\hline & Average & 0.96 & 0.88 & 1.21 & 0.84 & 0.97 & 55.37 \\
\hline Parameter $b^{*}$ & Label Rouge & 2.43 & 1.97 & 2.48 & 1.69 & $2.14 b$ & \\
\hline
\end{tabular}




\begin{tabular}{llllllll} 
& Pesadão & 2.33 & 1.53 & 2.63 & 2.17 & $2.17 \mathrm{a}$ & \\
Breat skin & Average & 2.38 & 1.75 & 2.55 & 1.93 & 2.15 & 49.35 \\
& & & & & & & \\
Parameter L* & Label Rouge & 66.40 & 63.32 & 63.66 & 63.75 & 64.28 & \\
& Pesadão & 67.07 & 63.70 & 64.52 & 64.88 & 65.04 & \\
& Average & 66.73 & 63.51 & 64.09 & 64.31 & 64.66 & 5.65 \\
Parameter a* & Label Rouge & 3.81 & 5.37 & 7.65 & 5.26 & 5.52 & \\
& Pesadão & 6.20 & 5.39 & 5.86 & 4.58 & 5.51 & \\
& Average & 5.00 & 5.38 & 6.75 & 4.92 & 5.51 & 25.42 \\
Parameter b* & Label Rouge & 12.30 & 14.07 & 17.82 & 15.81 & 15.00 & \\
& Pesadão & 16.68 & 14.57 & 17.61 & 17.70 & 16.64 & \\
Thigh skin & Average (L) & 14.49 & 14.32 & 17.71 & 16.75 & 15.82 & 19.95 \\
& & & & & & & \\
Parameter L* & Label Rouge & 58.05 & 56.83 & 58.24 & 57.54 & 57.67 & \\
& Pesadão & 57.09 & 53.71 & 57.14 & 54.94 & 55.72 & \\
& Average & 57.57 & 55.27 & 57.69 & 56.24 & 56.69 & 3.94 \\
Parameter a* & Label Rouge & 6.19 & 6.94 & 5.40 & 5.65 & 6.05 & \\
& Pesadão & 4.83 & 6.26 & 7.01 & 6.26 & 6.09 & \\
& Average & 5.51 & 6.6 & 6.20 & 5.59 & 5.98 & 26.96 \\
& Label Rouge & 10.29 & 8.25 & 8.45 & 10.05 & 9.26 & \\
Parameter b* & Pesadão & 10.00 & 6.71 & 11.92 & 9.01 & 9.41 & \\
& Average & 10.14 & 7.48 & 10.18 & 9.53 & 9.33 & 21.56 \\
\hline
\end{tabular}

Averages followed by different letters, lowercase in column, differ by the Newman-Keuls test $(\mathrm{P}<0.05) ; \mathrm{Q}=$ Quadratic effect and $\mathrm{L}=$ Linear effect; $\mathrm{VC}=$ coefficient of variation.

Table 3. Effects of strain and substitution levels of the diet for sugar cane upon temperature, $\mathrm{pH}$ and the parameters of color, meat, breast skin, in 24 hours after slaughter in the chickens

\begin{tabular}{|c|c|c|c|c|c|c|c|}
\hline \multirow{2}{*}{ Item } & \multirow{2}{*}{ Strain } & \multicolumn{5}{|c|}{ Diet substitution for sugarcane } & \multirow{2}{*}{$\begin{array}{l}\text { VC } \\
(\%)\end{array}$} \\
\hline & & $\mathbf{0 \%}$ & $15 \%$ & $30 \%$ & $45 \%$ & Average & \\
\hline \multirow{4}{*}{ Temperature } & Label Rouge & 5.21 & 5.01 & 3.34 & 3.74 & 4.33 & \\
\hline & Pesadão & 3.36 & 3.34 & 3.53 & 3.54 & 3.44 & \\
\hline & Average & 4.29 & 4.18 & 3.43 & 3.64 & 3.89 & 55.90 \\
\hline & Label Rouge & 5.42 & 5.41 & 5.42 & 5.37 & 5.41 & \\
\hline \multirow[t]{2}{*}{$\mathrm{pH}$} & Pesadão & 5.17 & 5.39 & 5.46 & 5.47 & 5.37 & \\
\hline & Average & 5.30 & 4.40 & 5.44 & 5.42 & 5.14 & 3.59 \\
\hline \multicolumn{8}{|l|}{ Breast meat } \\
\hline \multirow{4}{*}{ Parameter L* } & Label Rouge & 56.14 & 54.27 & 54.31 & 54.44 & 54.79 & \\
\hline & Pesadão & 53.23 & 52.99 & 54.05 & 54.28 & 53.64 & \\
\hline & Average & 54.68 & 53.63 & 54.18 & 54.36 & 54.21 & 4.49 \\
\hline & Label Rouge & 3.11 & 1.84 & 2.20 & 3.02 & 2.54 & \\
\hline \multirow[t]{2}{*}{ Parameter a* } & Pesadão & 1.85 & 2.14 & 1.68 & 1.72 & 1.85 & \\
\hline & Average & 2.48 & 1.99 & 1.94 & 2.37 & 2.20 & 36.18 \\
\hline \multirow{2}{*}{ Parameter b* } & Label Rouge & 6.57 & 1.84 & 2.20 & 5.93 & 4.14 & \\
\hline & Pesadão & 6.38 & 2.14 & 1.68 & 4.49 & 3.67 & \\
\hline
\end{tabular}




\begin{tabular}{llllllll}
\hline \multirow{2}{*}{ Breast skin } & Average $(\mathrm{Q})$ & 6.47 & 4.40 & 4.93 & 5.21 & 5.25 & 27.26 \\
& & & & & & & \\
Parameter L* & Label Rouge & 71.18 & 71.67 & 71.32 & 70.73 & 71.23 & \\
& Pesadão & 70.09 & 73.05 & 72.92 & 72.19 & 72.06 & \\
& Average & 70.63 & 72.36 & 72.12 & 71.46 & 71.64 & 3.13 \\
& Label Rouge & 4.73 & 3.89 & 4.35 & 5.20 & 4.54 & \\
Parameter a* & Pesadão & 5.09 & 4.18 & 3.79 & 3.66 & 4.18 & \\
& Average & 4.91 & 4.03 & 4.07 & 4.43 & 4.36 & 25.84 \\
& Label Rouge & 14.67 & 11.79 & 12.55 & 14.47 & 13.37 & \\
Parameter b* & Pesadão & 15.09 & 14.64 & 14.10 & 14.91 & 14.69 & \\
& Average & 14,88 & 13,22 & 13,32 & 14,69 & 14,03 & 15,51 \\
\hline
\end{tabular}

Averages followed by different letters, lowercase in the column, differ by the Newman-Keuls test $(\mathrm{P}<0,05) . \mathrm{Q}=$ Quadratic effect; $\mathrm{VC}=$ coefficient of variation.

It was no interaction $(\mathrm{P} \geq 0.05)$ between strains and treatments regarding carcass weight, 24 hours after slaughter (Table $3)$. There was no effect of the substitution levels $(\mathrm{P} \geq 0.05)$ upon the temperature and the $\mathrm{pH}$ of carcass.

24 hours after slaughter, it was observed quadratic effect $(\mathrm{P}<0.05)(\mathrm{Y}=6.2878-$ $\left.0.1293 \mathrm{X}+0.0023 \mathrm{X}^{2} . \mathrm{R}^{2}=0.79\right)$ of the substitution levels of the diet for sugar cane upon the parameter $b^{*}$ of breast (Table 2). The additional levels of color were not influenced by the diet substitution for sugar cane or strain $(\mathrm{P}>0.05)$ in 24 hours after slaughter.

There was no interaction between strains and substitution levels of the diet for sugar cane $(P \geq 0.05)$ and it was also not observed any effect of the strains to the absolute and relative weights of the viscera, cuts and carcass yields of chickens (Table 4). A linear effect of the substitution levels of diet for sugar cane $(\mathrm{P}<0.05)$ was observed on the weights of heart, liver, gizzard, abdominal fat, breast, thigh plus thigh and wing as well as to the carcass yield and the relative weight of heart and gizzard. The increase of diet substitution for sugar cane influenced negatively $(\mathrm{P}<0.05)$ the weight of heart, liver, breast, thigh plus thig, wing, carcass yield and relative weight of the animal heart. It was observed quadratic effect of the substitution levels for sugar cane $(\mathrm{P}<0.05)$ on the relative weight of the abdominal fat, being that the lower level of fat it was observed in the animals that ingested until $30 \%$ of sugar cane. 
Table 4. Effect of strain and substitution levels of the diet for sugarcane upon absolute and relative weight of edible offal and cuts, abdominal fat and carcass yield in the chickens

\begin{tabular}{|c|c|c|c|c|c|c|}
\hline \multirow{2}{*}{ Item } & \multicolumn{4}{|c|}{ Diet substitution for sugarcane } & \multirow{2}{*}{$\begin{array}{l}\text { Estimated } \\
\text { regression equation }\end{array}$} & \multirow{2}{*}{$\begin{array}{l}\text { VC } \\
(\%)\end{array}$} \\
\hline & $0 \%$ & $15 \%$ & $30 \%$ & $45 \%$ & & \\
\hline Carcass yield $(\%)^{1}$ & 69.4 & 69.08 & 67.50 & 66.67 & $\begin{array}{l}\mathrm{Y}=69.28-0.19 \mathrm{X}\left(\mathrm{R}^{2}\right. \\
=0.95)\end{array}$ & 2.98 \\
\hline \multicolumn{7}{|l|}{ Absolute weight (g) } \\
\hline Heart $^{1}$ & 22 & 21 & 21 & 16 & $\begin{array}{l}Y=22.812-0.363 X \\
\left(R^{2}=0.83\right)\end{array}$ & 13.90 \\
\hline Liver $^{1}$ & 58 & 61 & 62 & 53 & $\begin{array}{l}\mathrm{Y}=60.60-0.097 \mathrm{X} \\
\left(\mathrm{R}^{2=} 0.90\right)\end{array}$ & 9.59 \\
\hline Gizzard $^{1}$ & 63 & 73 & 77 & 82 & $\begin{array}{l}\mathrm{Y}=64.40+1.22 \mathrm{X}\left(\mathrm{R}^{2}\right. \\
=0.96)\end{array}$ & 11.44 \\
\hline Abdominal fat ${ }^{1}$ & 80 & 70 & 59 & 67 & $\begin{array}{l}Y=76.37-0.319 X \\
\left(R^{2}=0.54\right)\end{array}$ & 20.94 \\
\hline Breast ${ }^{1}$ & 679 & 670 & 629 & 570 & $\begin{array}{l}Y=692.28-7.35 X \\
\left(R^{2}=0.91\right)\end{array}$ & 8.95 \\
\hline Thigh + Thigh ${ }^{1}$ & 777 & 743 & 759 & 665 & $\begin{array}{l}Y=683.91-6.40 X \\
\left(R^{2}=0.70\right)\end{array}$ & 7.28 \\
\hline Wing 1 & 282 & 282 & 280 & 251 & $\begin{array}{l}Y=287.9-0.634 X \\
\left(R^{2}=0.64\right)\end{array}$ & 4.79 \\
\hline \multicolumn{7}{|l|}{ Relative weight (\%) } \\
\hline Heart $^{1}$ & 0.702 & 0.679 & 0.665 & 0.582 & $\begin{array}{l}Y=0.713-0.0075 X \\
\left(R^{2}=0.85\right)\end{array}$ & 12.54 \\
\hline Liver & 1.8 & 1.98 & 2.01 & 1.89 & NS & 9.72 \\
\hline Gizzard ${ }^{1}$ & 2.0 & 2.35 & 2.59 & 2.94 & $\begin{array}{l}\mathrm{Y}=2.00+0.062 \mathrm{X}\left(\mathrm{R}^{2}\right. \\
=0.99)\end{array}$ & 12.92 \\
\hline Abdominal fat ${ }^{2}$ & 2.34 & 2.12 & 1.79 & 2.22 & $\begin{array}{l}Y=2.38-0.36 \mathrm{X}+ \\
0.007 \mathrm{X}^{2}\left(\mathrm{R}^{2}=0.91\right)\end{array}$ & 20.17 \\
\hline Breast & 28.7 & 29 & 27.97 & 27.77 & NS & 3.75 \\
\hline Thigh + Thigh & 32.9 & 32.25 & 33.81 & 33.43 & NS & 3.86 \\
\hline Wing & 12.27 & 12.50 & 12.39 & 12.39 & NS & 4.52 \\
\hline
\end{tabular}

$\mathrm{L}=$ Linear effect and ${ }^{2} \mathrm{Q}=$ Quadratic effect $(\mathrm{P}<0,05) ; \mathrm{VC}=$ coefficient of variation; $\mathrm{NS}=$ Not Significant.

\section{DISCUSSION}

The absence of effect of the substitution level of diet for sugar cane on the temperature and $\mathrm{pH}$ of the chicken breast, which was observed in the present study, emphasizes that rarely a diet macroingredient affects physico- chemical characteristics of the meat (Faria et al., 2011; Alencar et al., 2014). Living muscles have $\mathrm{pH}$ value of 7.2 (obviously, the muscle do not constitute an ideal solution, being a semisolid tissue, which does not preclude the determination of its acid-base level, aiming the understanding of the chemical reactivity of the respective 
medium). After the slaughter, the meat continues in a biochemical process, in which the muscle energy is transformed in lactic glycogen through the action of several enzymes. The $\mathrm{pH}$ of the chicken meat decreases due to the acid formation, in which the breast meat should present final $\mathrm{pH}$ between 5.7 and 5.9. If the resulting $\mathrm{pH}$ is higher than 6.2 after 24 hours, the meat will present great water retention, implying in a small interval of the conservation time and, consequently, the occurrence of dark color, which characterizes the DFD meat (dark, firm, dry). If the $\mathrm{pH}$ value is lower than 5.8, until 4 hours after the slaughter, the PSE (pale, soft and exsudative) meat is obtained, which is characterizes by the small water retention, and pale and soft aspects.

Indeed, the $\mathrm{pH}$ of the meat is an important indicator of the meat quality since the $\mathrm{pH}$ value can be considered an indicator of biochemical and chemical processes that occur after slaughter. The substitution of diet for sugar cane did not alter the chicken meat characteristics in the present study, which allows to infer that, in agreement with the experimental results obtained, no damage occurred in the final product. Reinforcing the evidences identified in this study, works that investigated the use of other alternative feed as "guandu" beans (Alencar et al., 2014), corn grain silage (Saldanha et al., 2006), rice bran and cassava leaves (Faria et al., 2011), did not observe alteration in the $\mathrm{pH}$ value of broiler chicken meat. Sales (2014), in its work of meta-analysis, comparing chickens with and without access to fibrous material in the pastures form, did not identify significant difference. In fact, it was possible to observe only a tendency of $\mathrm{pH}$ increase, 24 hours after animal slaughter ( $\mathrm{pH} 24)$, when the chickens have access to the pasture. On the other hand, Castellini et al. (2002) registered lower value of $\mathrm{pH} 24$ in organic chickens as optimum condition of welfare, which reduced the stress as well as the pre-slaughter glycogen consumption.

The physicochemical characteristics of meat, skin and thigh were not influenced by the strains, except the parameter $\mathrm{a}^{*}$ to breast meat, in which the strain "Pesadão" presented higher value. The commercial strains of cutting chickens present lightly pink color in the breast meat (generating a less red color), which contributed to the difference observed between the broiler chickens in the parameter $\mathrm{a}^{*}$ of the typical color of the meat. In agreement with Qiao et al. (2001), the pre-slaughter management and the genetic predisposition are the main factors that influenced the meat color. However, Souza et al. (2011) did not found differences in the color of the chicken meat in the comparison of two strains to the semi-intensive production. Poultry diets are commonly cornsoybean meal-based displaying a high energy concentration and low fiber levels (Tufarelli et al., 2018). Nevertheless, many alternative feedstuffs with high fiber content such sugarcane bagasse (Kheravii et al., 2017; Kheravii et al., 2018a) and alfafa meal (Zheng et al., 2018) have been studied in poultry diet. These ingredients involved compounds such as $\beta$-carotenes, which is important active molecule in animal nutrition (Laudadio et al., 2014), that could alter the color of the skin and meat of broiler chickens.

It was verified that the utilization of sugar cane in the diets with broiler chickens promoted changes in the color of the chicken skins and meat, possibly due to the quantity of sugar cane leaf 
carotene and leaf / stem relation consumed by the chickens. However, Ponte et al. (2008a) observed that chickens were not submitted to pasture presented significant increase in the red color $\left(\mathrm{a}^{*}\right)$ in the carcass, showing that the undesirable intensities of pink and red in the skin were more developed in this case. These authors suggested a higher efficacy of the diet based on cereal to pigmentation of the carcass with yellow color, which can result of the high proportion of corn in the diet, despite the pasture to contain carotenoid pigments. These authors suggest a higher efficiency of the diet based on cereal to yellow pigmentation of the carcass, which can result of the high proportion of corn in the diet, despite the pasture to contain carotenoid pigments. In this way, the more intense color of the broiler chicken skin, submitted to diets with higher levels of green forages could increase the viability of carcass in the market. In fact, consumers usually associate the yellow color of skin and legs of chickens to a product originated of animal production characterized as similar to the natural conditions (Leeson $\&$ Summers, 2001).

The physicochemical properties of the meat, skin and thigh were not influenced by the strains. Similarly, Souza et al. (2011) did not find differences in the color of the chicken meat, when two strains were compared.

Results found in other experiments showed that the parameter of color $\mathrm{L}^{*}$ has been used to classify the chicken meats in light $\left(\mathrm{L}^{*}>53\right)$, dark $\left(\mathrm{L}^{*}<44\right)$ and normal $\left(44<\mathrm{L}^{*}<53\right)$ (Qiao et al., 2001). The results of this experiment demonstrated that the values of $\mathrm{L}^{*}$ are considered normal to luminosity (in terms of standard) of chicken meat), as function of the strains and the levels of the diet substitution.

The color observed in the surface of the meat is the result of the mild selective absorption by myoglobin. Considering that it is a hemoprotein, it presents a prosthetic group heme, with bands of absorption in the visible spectral region called band of Soret (or band B), bands $\mathrm{Q}$ and bands of charge-transfer. Indeed, the band of Soret, mainly, presents high molar absorptivity coefficient, i.e., generates great color intensity to its respective chemical environment, even when the sample is low concentration (which can be inferred through the absorption spectrum of the myoglobin heme group and its respective analysis through Lambert-Beer's Law).

The color changes of broiler chicken skins and meats that received sugar cane in diets can contribute to the product sell in market. Considering the sensorial properties, the color is one of the most important factors to the identification of the meat quality form the consumer. In fact, it is a characteristic that affects the initial choice of the product and can alter the decision of acquisition (Font-iFurnols \& Guerrero, 2014). In agreement with Banović et al. (2012), the meat color, probably, is not related directly with the consistence and organoleptic aspects of the product but develops an important role in the visual evaluation of the meat before intake.

Considering the parameters of meat quality usually considered, the color is one of the most important factors regarding the perception of food quality by the consumer, since it is a characteristic that affects the initial choice of product and its intake. This sensorial detection from consumers is determinant to the intake, suggesting something similar to the popular 
intuition that the chemical compounds that present chromophores (vide dyes and pigments) responsible for the color of the biological tissues are important parameters to indicate the quality of the respective tissue. This perception, which is based on the experience in the use of the product, frequently is justified, since relevant biological dyes of various tissues are analyzed as indicators of several biochemical processes.

The increase of the sugar cane inclusion in chicken diet have negatively affected the absolute weights of heart, liver, breast, thigh plus thigh and wing, being related to the effects in terms of performance. Consequently, the lower addition of nutrients, from the inclusion of an ingredient with lower levels of that respective nutrients, tends to cause reduction of the general performance of the animal. On the other hand, the absolute and relative weights of gizzards were the unique parameters that were increased by the sugar cane inclusion, which is justified by the lower levels of fibrous fraction related to the diets (and the mechanic breakage of these fibers, which is function of gizzard). The presence of particles with different sizes and characteristics in the diet can propitiate increase of the gizzard size by the higher crushing to the digestion of the nutrients (Kheravii et al., 2017; Kheravii et al., 2018b). Espósito et al. (2015) also registered increase of gizzard weight as function of the increase in the crushed sugar cane concentration (until $30 \%$ ) in diet of broiler chicken.

The decrease of the abdominal fat in carcass was one of the positive results of the substitution with sugar cane. However, Espósito et al. (2015), evaluating the inclusion of $15 \%$ and $30 \%$ of crushed sugar cane in diets to chickens, did not find alterations in the abdominal fat level. Together with the levels of substitution evaluated by Espósito et al. (2015), this work was also focused on supplementation of $45 \%$ of crushed sugar cane in the diet, which allows adjustment in the statistic model. The addition of crushed sugar cane in the diet of broiler chickens until 30\% generated a decrease of abdominal fat; Faria et al. (2011) registered that diets containing cassava leaf bran and rice bran originated lower abdominal fat in comparison with the control diet, corroborating the present data regarding the inclusion of sugar cane in the diet. The use of sugar cane as alternative food employed to compose until $45 \%$ in the diet of the broiler chickens favors to maintain the meat quality and reduces the abdominal fat level but decreases the carcass yield. The strains "Pesadão" and Label Rouge (LR) presented visceral composition as well as carcass and meat qualities similar to the animals that received sugar cane in comparison with the individuals that were treated with conventional diet.

\section{ACKNOWLEDGMENTS}

\author{
Ao Prof. Dr. Aldrin Vieira Pires (in \\ memoriam)
}

\section{REFERENCES}

ALENCAR, D.P.; MACIEL, M.P.; BOTELHO, L.F.R.; CALDEIRA, L.A.; SOUZA, L.P.M.; SILVA, D.B.; MOURA, V.H.S. Feijão guandu cru na alimentação de frangos caipiras criados em sistema semi-intensivo. Pesquisa Agropecuária Brasileira, v.49, n.9, p.737-744, 2014.

BANOVIĆ, M.; AGUIAR FONTES, M.; BARREIRA, M.M.; GRUNERT, 
K.G. Impact of product familiarity on beef quality perception. Agribusiness, v.28, p.157-172, 2012.

CALDARA, F.R.; SANTOS, V.M.O.; SANTIAGO, J.C.; ALMEIDA PAZ, I.C.L.; GARCIA, R.G.; VARGAS JÚNIOR, F.M.; SANTOS, L.S.; NÄÄS, I.A. Propriedades físicas e sensoriais da carne suína PSE. Revista Brasileira de Saúde e Produção Animal, v.13, n.3, p.815-824, 2012.

CASTELLINI, C.; MUGNAI, C.; DAL BOSCO, A. Effect of conventional versus organic method of production on the broiler carcass and meat quality. Meat Science, v.60, p.219-225, 2002.

CASTROMÁN, G.; DEL PUERTO, M.; RAMOS, A.; CABRERA, M.C.; SAADOUN, A. Organic and conventional chicken meat produced in Uruguay: Colour, $\mathrm{pH}$, fatty acids composition and oxidative status. American Journal of Food and Nutrition, v.1, p.12-21, 2013.

CRUZ, L.R.; GERASEEV, L.C.; CARMO, T.D.; SANTOS, L.D.T.; BARBOSA, E.A.; COSTA, G.A.; SANTOS JUNIOR, A. Características agronômicas e composição bromatológica de variedades de canade-açúcar. Bioscience Journal, v.30, n.6, p.1779-1786, 2014.

DETMANN, E.; SOUZA, M.A.; VALADARES FILHO, S.C.; QUEIROZ, A.C.; BERCHIELLI, T.T.; SALIBA, E.O.S.; CABRAL, L.S.; PINA, D.S.; LADEIRA, M.M.; AZEVEDO, J.A.G. Métodos para análise de alimentos. INCT - Ciência Animal. Visconde do Rio Branco: Suprema, 2012. 214p.
ESPÓSITO, M.; FASSANI, E.J.; CLEMENTE, A.H.S.; MAIKYAMA, L.; RETES, P.L.; CASTRO, S.F. Uso da cana de açúcar triturada na alimentação de frangos de corte tipo caipira. Boletim de Indústria Animal, v.72, n.2, p.129-136, 2015. FARIA, P.B.; VIEIRA, J.O.; SILVA, J.N.; RODRIGUES, A.Q.; SOUZA, X.R.; SANTOS, F. R.; PEREIRA, A.A. Performance and carcass characteristics of free-range broiler chickens fed diets containing alternative feedstuffs.

Brazilian Journal of Poultry Science, v.13, n.3, p.211-216, 2011.

FONT-I-FURNOLS, M.; GUERRERO, L. Consumer preference, behavior and perception about meat and meat products: An overview. Meat Science, v.98, n.3, p.361-371, 2014.

HOLANDA, M.A.C.; HOLANDA, M.C.R.; VIGODERES, R.B.; DUTRA JUNIOR, W.M.; ALBINO, L.F.T. Desempenho de frangos caipiras alimentados com farelo integral de mandioca. Revista Brasileira de Saúde e Produção Animal, v.16, n.1, p.106117, 2015.

IPEK, A.; SOZCU, A. The effects of access to pasture on growth performance, behavioural patterns , some blood parameters and carcass yield of a slow-growing broiler genotype. Journal of Applied Animal Research, v.45, n.1, p.464-469, 2017.

KHERAVII, S.K.; MORGAN, N.K.; SWICK, R.A.; CHOCT, M.; WU, S. Roles of dietary fibre and ingredient particle size in broiler nutrition.

World's Poultry Science Journal, v.74, p.1-16, 2018 b. 
KHERAVII, S.K.; SWICK, R.A.; CHOCT, M.; WU, S. Dietary sugarcane bagasse and coarse particle size of corn are beneficial to performance and gizzard development in broilers fed normal and high sodium diets. Poultry Science, v.96, p.4006-4016, 2017.

KHERAVII, S.K.; SWICK, R.A.; CHOCT, M.; WU, S. Nutrient digestibility response to sugarcane bagasse addition and corn particle size in normal and high $\mathrm{Na}$ diets for broilers. Poultry Science, v.0, p.1-7, 2018a.

LAUDADIO, V.; CECI, E.; LASTELLA, N.M.B.; INTRONA, M.; TUFARELLI, V. Low-fiber alfalfa (Medicago sativa L.) meal in the laying hen diet: Effects on productive traits and egg quality. Poultry Science, v.93, n.7, p.1868-1874, 2014.

LEAL, M.R.L.V.; GALDOS, M.V.; SCARPARE, F.V.; SEABRA, J.E.A.; WALTER, A.; OLIVEIRA, C.O.F. Sugarcane straw availability, quality, recovery and energy use: A literature review. Biomass and Bioenergy, v.53, p.11-19, 2013.

PONTE, P.I.P.; ALVES, S.P.; BESSA, R.J.B.; FERREIRA, L.M.A.; GAMA, L.T.; BRÁS, J.L.A.; FONTES, C.M.G.A.; PRATES, J.A.M. Influence of pasture intake on the fatty acid composition, and cholesterol, tocopherols and tocotrienols content in meat from free-range broilers. Poultry Science, v.87, p.80-88, 2008a.

PONTE, P.I.P.; ROSADO, C.M.C.; CRESPO, J.P.; CRESPO, D.G.; MOURÃO, J.L.; CHAVEIROSOARES, M.A.; BRAS, J.L.A.;
MENDES, I.; GAMA, L.T.; PRATES, J.A.M.; FERREIRA, L.M.A.; FONTES, C.M.G.A. Pasture intake improves the performance and meat sensory attributes of free-range broilers. Poultry Science, v.87, p.71-79, 2008b.

QIAO, M.; FLETCHER, D.L.; SMITH, D.P.; NORTHCUTT, J.K. The effect of broiler breast meat color on $\mathrm{pH}$, moisture, water-holding capacity, and emulsification capacity. Poultry Science, v.80, p.676-680, 2001.

RANJITKAR, S.; KARLSSON, A.H.; PETERSEN, M.A.; BREDIE, W.L.P.; PETERSEN, J.S.; ENGBERG, R.M. The influence of feeding crimped kernel maize silage on broiler production, nutrient digestibility and meat quality. British Poultry Science, v.57, n.1, p.93-104, 2016.

ROSTAGNO, H.S.; ALBINO, L.F.T.; DONZELE, J.L. et al. Tabelas brasileiras para aves e suínos. (Composição de alimentos e exigências nutricionais). Viçosa: UFV, 2005.

SALDANHA, E.S.P.B.; MENDES, A.A.; PIZZOLANTE, C.C.;

TAKAHASHI, S.E.; KOMIYAMA, C.M.; GARCIA, R.G.; BALOGNETO, A.; PAZ, I.C.L.A.; GARCIA, E.A.; DALANEZI, J.Á.; QUINTEIRO, R.R. Performance, carcass yield, and meat quality of free-range broilers fed wet grain corn silage. Brazilian Journal of Poultry Science, v.8, n.2, p.113-118, 2006.

SALES, J. Effects of access to pasture on performance, carcass composition, and meat quality in broilers: A metaanalysis. Poultry Science, v.93, p.15231533, 2014. 
SOUZA, X.R.; FARIA, P.B.;

BRESSAN, M.C. Proximate

composition and meat quality of

broilers reared under different

production systems. Brazilian Journal

of Poultry Science, v.13, n.1, p.15-20,

2011.

STADIG, L.M.; RODENBURG, T.B.;

REUBENS, B.; AERTS, J.;

DUQUENNE, B.; TUYTTENS, F.A.M.

Effects of free-range access on

production parameters and meat quality, composition and taste in slow-growing broiler chickens. Poultry Science, v.95, n.12, p.2971-2978, 2016.

TUFARELLI, V.; RAGNI, M.;

LAUDADIO, V. Feeding Forage in Poultry : A Promising Alternative for the Future of Production Systems.

Agriculture, v.8, p.1-10, 2018.

ZHENG, M.; MAO, P.; TIAN, X.;

GUO, Q.; MENG, L. Effects of dietary supplementation of alfalfa meal on growth performance, carcass characteristics, meat and egg quality, and intestinal microbiota in Beijing-you chicken. Poultry Science, v.0, p.1-10, 2018. 